\title{
Determinants of Teacher Performance with Job Satisfactions Mediation
}

\section{Arief Tukiman Hendrawijaya}

Dr., corresponding author, Faculty of Teacher Training and Education, University of Jember, Jember, Indonesia, hendrawijayapls.fkip@unej.ac.id

\section{Muhammad Irfan Hilmi}

Faculty of Teacher Training and Education, University of Jember, Jember, Indonesia, irfanhilmi.fkip@unej.ac.id

\section{Fuad Hasan}

Faculty of Teacher Training and Education, University of Jember, Jember, Indonesia, fuadhasan@unej.ac.id

\section{Niswatul Imsiyah}

Faculty of Teacher Training and Education, University of Jember, Jember, Indonesia, niswatul@unej.ac.id

\section{Deditiani Tri Indrianti}

Faculty of Teacher Training and Education, University of Jember, Jember, Indonesia, indrianti_pkp.fkip@unej.ac.id

This paper is about teacher performance. This study aims to analyze and assess the effects of performance allowance, work discipline, work culture, and leadership on teacher performance viewed from direct effect and indirect effect with job satisfaction as the mediation. The quantitative method was used in this study. This research applied explanatory research involving elementary school teachers as the research samples in the Jember Regency.Data analysis uses path analysis to determine the direct and indirect effects. The study showed that performance allowance, work discipline, work culture, and leadership directly affected job satisfaction and also teacher performance. Job satisfaction mediated the effect of performance allowance, work discipline, work culture and leadership on teacher performance.

Keywords: performance allowance, work discipline, work culture, leadership, job satisfaction, teacher performance

Citation: Hendrawijaya, A. T., Hilmi, M. I., Hasan, F., Imsiyah, N., \& Indrianti, D. T. (2020). Determinants of Teacher Performance with Job Satisfactions Mediation. International Journal of Instruction, 13(3), 845-860. https://doi.org/10.29333/iji.2020.13356a 


\section{INTRODUCTION}

Human resource management is the development and utilization of personnel for effective achievement of individual, organization, community, national, and international goals and targets (Ivancevich and Matteson. 2005). One way to improve the quality of human resources is through education. Development in the field of education has a reciprocal relationship with attempts to improve human resources, and both of these affect each other. Education is a conscious and planned effort to realize a learning process that will actively develop students' self-potential to have spiritual strength, self-control, personality, intelligence, noble characters as well as skills needed by themselves, society, nation, and country.

The teacher is a professional job with the main tasks of educating, teaching, guiding, directing, training, assessing, and evaluating students. Teaching is a component that must exist in the world of education. The teacher's role cannot be ignored because, without teachers, education cannot be performed. In the learning process and improving the quality of education, the role of a teacher is important. Without an optimal teacher role, the learning process in education will not run well. Therefore, teacher quality is one of the most important factors to improve the quality of education.

Performance allowance is allowance given to the workers by institution where they worked based on the criteria made from the institution. Performance allowance isa determinant of job satisfaction and teacher performance, so it should receive more attention. Previous studies found that performance allowance has a positive effect on performance (Birnbaun, 1998); (Ibojo, and Asabi, 2014). Unfairness in providing performance allowance is a source of dissatisfaction which ultimately can lead to disputes and low level of performance (Strauss and Corbin, 1990). Performance allowance does not always affect job performance due to other influencing factors (Hameed, et al., 2014); (Jamil and Raja. 2011).

Work discipline is a form of compliance or compliance with government regulations or rules or ethics, norms, and rules that apply in society. Compliance is done by humans within a community. A group of people who are disciplined in their lives will create a disciplined society, and a disciplined society will manifest in a disciplined state (Cedaryana, et al., 2015); (Nugroho and Hastuti, 2019). Without good employee discipline, it is difficult for the organization to achieve optimal results. Employee discipline can be seen from the presence of employees every day, the accuracy of working hours, the wearing of work clothing and identification, and employee compliance with regulations (Hewett et al., 2018).

Leadership, in general, will involve a process of social influence, which is intentionally carried out by someone in another person, to arrange activities and relationships in a group or organization (Burns, 2003). The leadership role is considered successful in an organization when leaders are able to improve one's performance and organizational performance. The relationship between transactional leaders and employees can be reflected in three aspects (Bass and Avolio., 2002) including: (1) leaders' understanding of the desires of subordinates and communication with them to explain the rewards that 
will be given for expected performance; (2) the exchange of efforts and achievements of the teacher in return; and, (3) leaders responsiveness to teacher interest provided that it is consistent with the achievement.

Teacher satisfaction with their work could be used by school leaders to identify aspects related to teacher professional behavior, school effectiveness improvement, and organizational performance (Alonderiene et al., 2016). Laurian-Fitzgerald and Fitzgerald (2017) mention that teacher awareness related to nationalism also influences performance and contributes to the effectiveness of organizational competitiveness.

Afshar and Doosti (2016) examined the effect of satisfaction on the performance of Iranian English Teachers. Using 64 Iranian English teachers and 1774 students as a sample, this study found that there were differences in teacher satisfaction with their work caused by their perceptions of the teaching profession. Talabi (2016) conducted a study to investigate the satisfaction and performance of public secondary school teachers. Using 200 public high school teachers from the West Akoko Nort Regional Government Area in Ondo as a sample, this study found that teacher satisfaction was influenced by salary, incentives, promotion opportunities, recognition, and increased qualifications. If all these things are not met by the school, the teacher will be apathetic and not motivated at work.

Amalia \& Pilarta (2015) conducted research to investigate whether teacher satisfaction, teacher performance, and student academic achievement were positively related significantly. By using 80 teachers and 1500 students as respondents, this study found that teacher satisfaction with their work affects student achievement. Teacher satisfaction is influenced by promotion opportunities and employment status. Fashiku (2016) investigated the communication patterns of influential leaders and the performance of lecturers at the Kwara State College of Education, Nigeria. The results found that teacher satisfaction is influenced by government and school policies that are applied primarily to the improvement and recognition of the teaching profession.

More than a quarter of teachers are not in Arizona, the US is dissatisfied with their work and agrees to quit because of school status (Mertler, 2016). School' reputation is one of the keys in influencing teacher performance related to aspects of emotional intelligence (Liu et al., 2016). But the study has not been linked to aspects of leadership and school organizational style. Principals who have good behavior affect the behavior and performance of teachers at the school (Miao et al., 2018). Previous studies did not discuss comprehensively related to the relationship between performance allowance, work discipline, work culture, and leadership on teacher performance.

Many problems currently emerge concerning teacher performance, especially those occurring in the Jember Regency, Indonesia. Teacher performance is said to be relatively low, which can be seen from several things (1) teachers educate students by using a system that is in accordance with the curriculum and teaching time, but, currently, there are still many teachers who teach not in accordance with the curriculum and have less teaching time than their teaching hours, (2) in schools there are rules that bind teachers and students to obey applicable regulations, but at present there are still 
many teachers who violate these rules such as arriving late, (3) theoretically, teachers who receive a higher income will be better in performance, but, in reality, not all teachers who have work benefits have good performance.

The aim of this study is to analyze and examine whether performance allowance, work discipline, work culture and leadership affect teacher performance directly or indirectly by mediating job satisfaction.

\section{LITERATURE REVIEW}

\section{Relationship between Performance Allowance, Work Discipline, Work Culture, Leadership with Teacher Performance Mediated by Job Satisfaction}

Performance allowance is an effort that is often done to improve teacher performance, but other factors such as work culture, discipline, and leadership can also be considered to improve teacher performance. Teacher's performance will be maximal and continue to increase if the teacher is satisfied with the performance allowance provided by the school, and conversely, the teacher's performance will decrease if the teacher is disappointed with the performance allowance of the company. Performance benefits that are given fairly will contribute to teacher satisfaction and will ultimately affect the teacher's performance. Thus, teacher performance will increase or decrease according to the level of teacher job satisfaction based on performance benefits provided by the school. (Luthans, 2009). Psychosocial factors can affect teacher performance. Psychosocial factors can affect teacher performance. One of these factors is influenced by teacher work experience (Odebode, 2018).

Implementation of discipline for employees is expected to improve employee performance. Additionally, discipline needs to be supported by a good work environment that can support efficiency, security, safety, cleanliness, and comfort in work and the existence of adequate facilities, so that employees feel safe, calm and happy in carrying out their assigned duties and responsibilities, and teacher satisfaction increases. High work discipline will be able to help improve performance (Luthans, 2009). Implementation of discipline for employees is expected to improve employee performance. In addition, implementation of discipline needs to be supported by a good work environment that can support efficiency, security, safety, cleanliness, and comfort in work and the existence of adequate facilities, so that employees feel safe, calm and happy in carrying out their assigned duties and responsibilities. Leadership, work culture, and competency development facilities greatly affect teacher performance. A good leader will certainly pay attention to teacher satisfaction factors, so that work culture and competence could be improved (Toha \& Katoningsih, 2018)

Work culture greatly influences a teacher when carrying out his or her duties at school. A work environment is said to be good if the teacher can carry out activities optimally, healthily, safely and comfortably. A good work culture will make the teacher feel comfortable doing his work. Work will be performed well if it is supported by a good culture. This, of course, has an effect on teacher job satisfaction. The teacher will feel satisfied working in a school if it is supported by a work culture that can make it comfortable, whereas if the environment is not comfortable, it will result in the teacher's 
feeling of dissatisfaction. so that he becomes less enthusiastic in and carrying out his duties as a teacher. If he feels dissatisfied, his performance will automatically decrease.

Work culture is important to improve the quality of learning in multicultural students. This is related to the characteristics of countries that have ethnic diversity (Stroganova et al., 2019). Teacher's work motivation is influenced by job satisfaction. Good job satisfaction is determined by a good organizational culture which will ultimately improve teacher performance (Hutabarat, 2015).

work culture and togetherness at work affect teacher satisfaction and performance. It will also improve the quality of learning in schools (Song et al., 2018).

Leadership is the way a leader manages and controls his subordinates. Through leadership, a leader is expected to be able to overcome various problems by utilizing existing resources, both capital resources and human resources, effectively and efficiently, so that work goals can be achieved. The most appropriate leadership can maximize productivity, job satisfaction, growth and easy adaptation to all situations. The right leadership will be able to create a conducive work environment for employees, a good working relationship between employees and superiors, and a disappearance of social disparity between lines within the company. Each of these factors will create a comfortable working atmosphere for all parties, including the teacher. The teacher will feel satisfied when working in good conditions or situations that are in accordance with the teacher's expectations (Quddus \& Ahmed, 2017).

Related to job satisfaction, Luthans (2011) says that job satisfaction is a pleasant or positive emotional state that arises or results from an assessment of performance. Employees with high levels of satisfaction will perform well, even though the results are not immediate. Satisfaction felt by the teacher at work will provide encouragement to work better and achieve more. Thus, when leadership is implemented properly and correctly, it will have an influence on teacher performance through employee job satisfaction. The right leadership will be able to create a conducive work environment and make the teacher feel comfortable at work; this, in turn, makes the teacher feels happy and satisfied which will affect the teacher's performance. Teachers' high levels of job satisfaction, due to the right leadership, will have a positive effect on their performance.

Based on theoretical and empirical studies, the following framework and hypothesis can be presented as follows: 


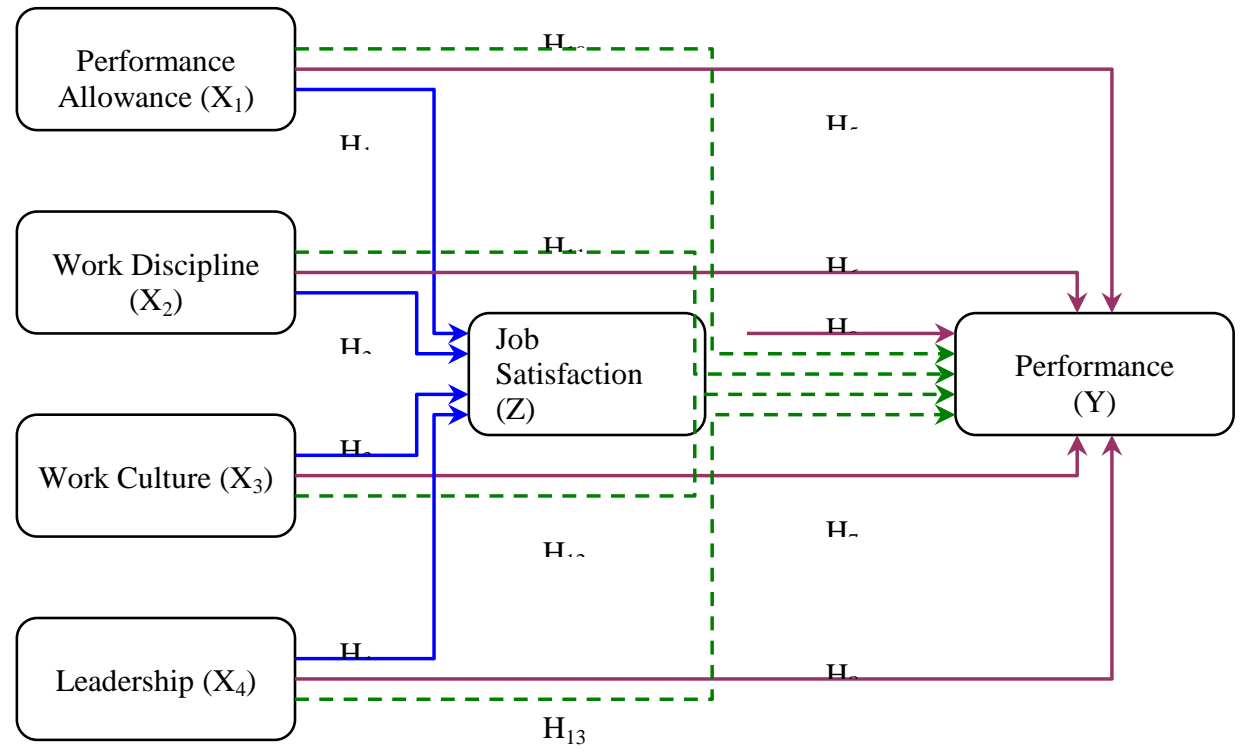

Figure 1

Research Conceptual Framework

Notes:

: Direct influence

indirect influence

This experiment has been accepted by the academic senate of University of Jember as an ethical committee. The study complies with all regulations and confirmation that informed consent was obtained.

\section{METHOD}

The population of this study was all elementary school teachers in the Jember Regency, totaling 9,809 teachers. The inclusion criteria of this study were elementary school teachers who hold the status of civil servants and have a tenure of more than 10 years. This was, in total, 4,904 teachers. By using sampling calculation, a minimum sample of 99 respondents was obtained, but considering the accuracy of the data the respondents taken were as many as 250 respondents.

Data collection techniques used were observation and questionnaire. Questionnaires were (data collection) carried out from April to July 2018.Questionnaires used a 5-point Likert scale adapted from the literature related to research. Observation aims to observe the behavior of teachers at work that represents satisfaction with their work. The measurement of performance allowance variables adopted a questionnaire developed by Opshal and Dunnette (Opshal and Dunnette, 1996) and David (David, 2006). Measurement of work discipline variables adopted a questionnaire developed by Cedaryana (Cedaryana et al, 2018). The measurement of work culture variable adopted a questionnaire developed by Robbins (Robbins, 2006). Measurement of leadership 
variable adopted a questionnaire developed by Luthan (Luthan, 2009). The measurement of job satisfaction variable was adopted from a questionnaire developed by Smith (Smith, 1975). The measurement of performance variable adopted a questionnaire developed by Osborn and Gabler (Osborn and Gabler, 1992) and Micheli and Neely (Micheli and Neely, 2010).

The results of the instrument validity test on the variables of performance allowance, work discipline, work culture, leadership, job satisfaction and teacher performance indicated a correlation coefficient from 0.447 to 0.627 with a significance value between 0,000 , thus indicating a significance value of less than $\alpha(0.05)$. This means that all items in each variable of this study are valid. Instrument reliability testing obtained Cronbach's Alpha coefficient values ranging from $0.602-0.655$ and greater than 0.60 , so the variable instruments in the study are declared reliable (Hair et al., 2010).

Path analysis was used as a method of data analysis with the aim of identifying the direct effect of performance allowance, work discipline, work culture and leadership on teacher performance and the indirect effect of performance allowance, work discipline, work culture and leadership on teacher performance mediated by job satisfaction.

\section{FINDINGS}

\section{General Description of Respondents}

The research samples were 250 respondents consisting of elementary school teachers in Jember Regency who had the status of civil servant and had more than 10 years of service. Data on the respondents' characteristics include age, gender, latest education and length of service. The description of each respondent's characteristics is presented in Table 1.

Table 1

Description of Respondents' Characteristics

\begin{tabular}{llll}
\hline \multirow{2}{*}{ Characteristics } & \multirow{2}{*}{ Description } & Distribution & \\
\cline { 3 - 4 } & & Frequency & Percentage (\%) \\
\hline Age & 25-35 years & 46 & 18.4 \\
\hline & 36-45 years & 94 & 37.6 \\
\hline & 46-55 years & 106 & 42.4 \\
\hline Gender & $>55$ years & 4 & 1.6 \\
\hline & Male & 87 & 34.8 \\
\hline Education & Female & 163 & 65.2 \\
\hline & Senior High School & 42 & 16.8 \\
\hline & Diploma & 138 & 55.2 \\
\hline Length of service & Bachelor & 68 & 27.2 \\
\hline & Master & 2 & 0.8 \\
\hline & $10-20$ years & 103 & 41.2 \\
\hline Total & $21-30$ years & 100 & 40.0 \\
\hline
\end{tabular}

Table 1 shows that most of the research respondents are in the age of 46-55 years old $(42.4 \%)$, female $(65.2 \%)$, diploma-educated both Diploma 2 or Diploma $3(55.2 \%)$ and 
have a period of employment between 10 to 20 years $(41.2 \%)$. It means that most respondents have graduated from college with long working experience.

\section{Path Analysis}

The results of direct testing of the effect of performance allowance, work discipline, work culture and leadership on job satisfaction and the effect of performance allowance, work discipline, work culture, leadership and job satisfaction on teacher performance are presented in Table 2.

Table 2

Hypothesis Testing of Direct Effect

\begin{tabular}{|c|c|c|c|c|}
\hline Hypothesis & Regression Model & Direct Effect & t-count & Sig. \\
\hline $\mathrm{H}_{1}$ & $\begin{array}{l}\text { Performance allowance }\left(\mathrm{X}_{1}\right) \\
\rightarrow \text { Job satisfaction }(\mathrm{Z})\end{array}$ & 0.132 & 2.058 & $0.041 * *$ \\
\hline $\mathrm{H}_{2}$ & $\begin{array}{l}\text { Work discipline }\left(\mathrm{X}_{2}\right) \\
\rightarrow \text { Job Satisfaction }(\mathrm{Z})\end{array}$ & 0.127 & 2.034 & $0.043 * *$ \\
\hline $\mathrm{H}_{3}$ & $\begin{array}{l}\text { Work culture }\left(\mathrm{X}_{3}\right) \\
\rightarrow \text { Job satisfaction }(\mathrm{Z})\end{array}$ & 0.125 & 2.033 & $0.043 * *$ \\
\hline $\mathrm{H}_{4}$ & $\begin{array}{l}\text { Leadership }\left(\mathrm{X}_{4}\right) \\
\rightarrow \text { Job satisfaction }(\mathrm{Z})\end{array}$ & 0.154 & 2.408 & $0.017 * *$ \\
\hline $\mathrm{H}_{5}$ & $\begin{array}{l}\text { Performance allowance }\left(\mathrm{X}_{1}\right) \\
\rightarrow \text { Teacher performance }(\mathrm{Y})\end{array}$ & 0.221 & 3.661 & $0.000 * * *$ \\
\hline $\mathrm{H}_{6}$ & $\begin{array}{l}\text { Work discipline }\left(\mathrm{X}_{2}\right) \\
\rightarrow \text { Teacher performance }(\mathrm{Y})\end{array}$ & 0.153 & 2.601 & $0.010 * *$ \\
\hline $\mathrm{H}_{7}$ & $\begin{array}{l}\text { Work culture }\left(\mathrm{X}_{3}\right) \\
\rightarrow \text { Teacher performance }(\mathrm{Y})\end{array}$ & 0.153 & 2.646 & $0.009 * * *$ \\
\hline $\mathrm{H}_{8}$ & $\begin{array}{l}\text { Leadership }\left(\mathrm{X}_{4}\right) \\
\rightarrow \text { teacher performance }(\mathrm{Y})\end{array}$ & 0.119 & 1.974 & $0.049 * *$ \\
\hline $\mathrm{H}_{9}$ & $\begin{array}{l}\text { Job satisfaction }(\mathrm{Z}) \\
\rightarrow \text { Teacher performance }(\mathrm{Y})\end{array}$ & 0.151 & 2.532 & $0.012 * * *$ \\
\hline
\end{tabular}

Hypothesis testing of the direct effect (Table 2) shows that all coefficients are positive, which means that each increase in the independent variables (Performance Allowance, Work Discipline, Work Culture and Leadership) will be followed by an increase in the dependent variables (Job Satisfaction and Teacher Performance). It is necessary to increase performance allowances regularly based on work experience and experience, strengthening work culture, and good and egalitarian leadership

Testing of the indirect effect of performance allowance, work discipline, work culture and leadership on teacher performance mediated by job satisfaction is presented in Table 3. 
Table 3

Hypothesis Testing of Indirect Effect

\begin{tabular}{lllll}
\hline Hypothesis & Regression Model & Indirect Effect & t-count & Sig. \\
\hline $\mathrm{H}_{10}$ & $\begin{array}{l}\text { Performance allowance }\left(\mathrm{X}_{1}\right) \rightarrow \text { Job } \\
\text { satisfaction }(\mathrm{Z}) \rightarrow \text { Teacher performance }(\mathrm{Y})\end{array}$ & 0.020 & 2.122 & $0.037 * *$ \\
\hline $\mathrm{H}_{11}$ & $\begin{array}{l}\text { Work discipline }\left(\mathrm{X}_{2}\right) \rightarrow \text { Job satisfaction }(\mathrm{Z}) \\
\rightarrow \text { Teacher performance }(\mathrm{Y})\end{array}$ & 0.019 & 2.153 & $0.034 * *$ \\
\hline $\mathrm{H}_{12}$ & $\begin{array}{l}\text { Work culture }\left(\mathrm{X}_{3}\right) \rightarrow \text { Job satisfaction }(\mathrm{Z}) \rightarrow \\
\text { Teacher performance }(\mathrm{Y})\end{array}$ & 0.019 & 2.143 & $0.035 * *$ \\
\hline $\mathrm{H}_{13}$ & $\begin{array}{l}\text { Leadership }\left(\mathrm{X}_{4}\right) \rightarrow \text { Job satisfaction }(\mathrm{Z}) \rightarrow \\
\text { Teacher performance }(\mathrm{Y})\end{array}$ & 0.023 & 2.300 & $0.024 * *$ \\
\hline
\end{tabular}

Note: $* *$ significant is at $\alpha=5 \%$

Table 3 shows that hypothesis testing of an indirect effect demonstrates that all pathways indirectly have a significant effect. Job satisfaction mediates the effect of performance allowance, work discipline, work culture and leadership on teacher performance. Teacher performance does not only focus on achievement and the ability to deliver knowledge to students, but also needs to be evaluated by considering aspects of organizational work culture and leadership of the school principal.

Testing of direct, indirect and total effect of the variables of performance benefits, work discipline, work culture, leadership, job satisfaction and teacher performance is presented in Table 4.

Table 4

Direct, Indirect and Total Effects

\begin{tabular}{llll}
\hline Regression Model & Direct Effect & Indirect Effect & Total Effect \\
\hline Performance allowance $\left(\mathrm{X}_{1}\right) \rightarrow$ Teacher performance $(\mathrm{Y})$ & 0.221 & 0.020 & 0.241 \\
\hline Work discipline $\left(\mathrm{X}_{2}\right) \rightarrow$ Teacher performance $(\mathrm{Y})$ & 0.153 & 0.019 & 0.172 \\
\hline Work culture $\left(\mathrm{X}_{3}\right) \rightarrow$ Teacher performance $(\mathrm{Y})$ & 0.153 & 0.019 & 0.172 \\
\hline Leadership $\left(\mathrm{X}_{4}\right) \rightarrow$ Teacher performance $(\mathrm{Y})$ & 0.119 & 0.023 & 0.142 \\
\hline
\end{tabular}

Based on the table, it is known that each total effect of the independent variables has a performance allowance of $24.1 \%$, work discipline of $17.2 \%$, work culture of $17.2 \%$ and leadership of $14.2 \%$. Work allowances and work culture are factors that can be improved by schools to improve teacher performance. Briefly the results of path analysis testing are summarized in Figure 2. 


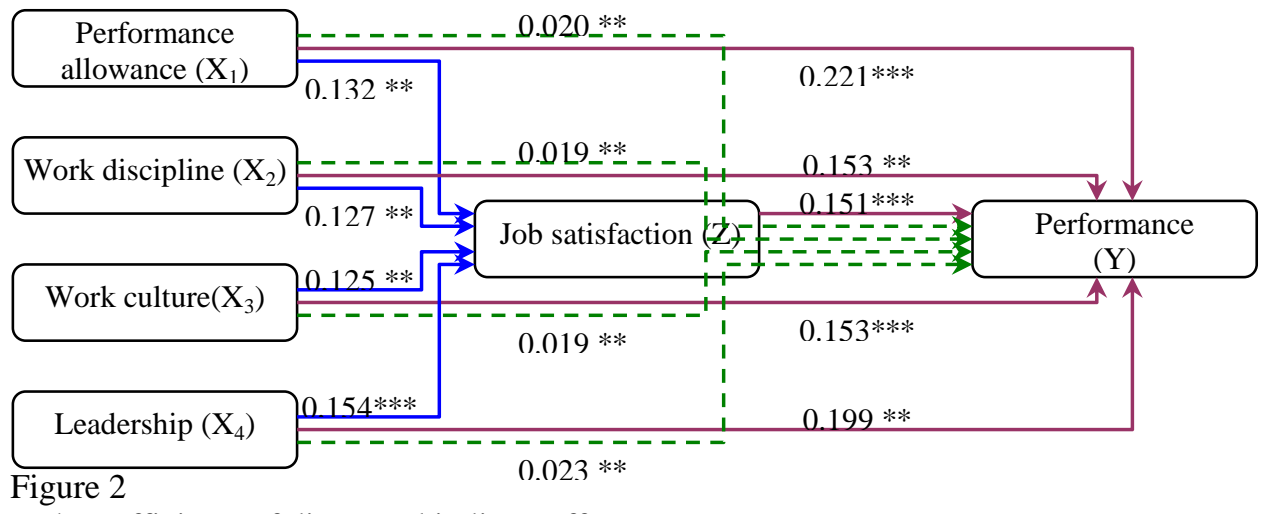

Path coefficients of direct and indirect effect

Observation results show that teacher satisfaction with work is not only related to work benefits, but also work culture in schools. A good work culture needs to be improved so that all teachers feel that the workload obtained is in accordance with the principle of justice. School leaders must also conduct a self-evaluation to improve the quality of their leadership, especially with regard to firmness, discipline, and transparency.

\section{DISCUSSION}

Performance allowance is what teachers receive in exchange for their contribution to the school. Performance allowance helps schools achieve their goals and obtain and retain productive teachers (Dessler, 2010). Performance allowance has a positive and significant effect on job satisfaction. This means that the greater the performance allowance received by the teacher, the more satisfied the teacher will be at work.

Work discipline has a positive and significant effect on job satisfaction. This can be interpreted that indicators in the work discipline are able to increase job satisfaction. According to Byars-Rue, discipline must be seen as a learning opportunity for teachers and as a tool to increase productivity and human relations, which means that teachers who have high discipline in the learning process will easily increase job satisfaction (Byars-Rue, 2004).

The calculation results show that work culture has a positive and significant effect on job satisfaction. These results mean that indicators in the work culture are able to increase job satisfaction. A good work culture will make the teacher feel more comfortable in doing his or her work. Work will be done well if it is supported by a good culture. This, of course, influences teacher job satisfaction. The teacher will feel satisfied working in a school if he or she is supported by a comfortable work culture.

Leadership has a positive and significant effect on job satisfaction, which means that indicators in leadership can improve job satisfaction. According to Colquitt et al., leadership is the use of strength and influence on direct subordinates to achieve goals 
(Colquitt et al., 2009). Leadership is a person's ability to influence, motivate others to be able to contribute towards achieving organizational effectiveness and success.

This study found that performance allowances has a positive and significant effect on teacher performance. This means that the higher the teacher's work allowance, the higher their performance. Performance allowance in schools means reward or appreciation for employees who have contributed in realizing their goals through good performance. The results of previous studies found that the performance allowance variable has a strong and significant relationship with employee performance (Elqadri et al., 2013); (Rizal et al., 2012). Other studies find that good performance allowance remains a strategy to motivate employees to improve performance (Yamoah, 2011).

Work discipline has a positive and significant effect on teacher performance. This means that indicators of work discipline can improve teacher performance. Implementation of discipline for employees is expected to improve employee performance. Besides, it needs to be supported by a good work environment that can support efficiency, security, safety, cleanliness, and comfort in work and the existence of adequate facilities make employees feel safe, calm and happy in carrying out their assigned duties and responsibilities. (Luthan, 2009).

Teacher performance is also affected by work culture. Susilowati's study confirms that the effect of organizational culture on teacher performance through learning organization is significant and positive. In addition, the effect of individual competencies on teacher performance through learning organizations is also significant and positive (Susilowati, 2013). The implication of this research is that each school organization has a strategy to improve teacher performance so that teachers can build, improve, and maintain a high organizational culture and continuously develop individual competencies with strategies to create learning organizations in such a way that they will improve teacher performance.

Leadership has a positive and significant effect on teacher performance which means that indicators of leadership can improve teacher performance. Riaz and Haider found that leaders facilitate a new understanding by increasing or changing awareness of problems (Riaz and Haider, 2010). Finally, leadership will grow inspiration and enthusiasm to put extra effort to achieve common goals.

Job satisfaction has a significant positive effect on teacher performance. This can be interpreted that indicators of job satisfaction can improve teacher performance. The more factors in the work environment that are in accordance with the teachers' wishes and needs, the higher the satisfaction and the better the performance of the teacher, and vice versa. The results of this study support two previous studies that found the positive and significant relationship between job satisfaction and employee performance (Munawaroh et al, 2011); (Saeed et al, 2011).

Job satisfaction mediates the effect of performance allowance on teacher performance. This means that indicators of performance allowance can improve teacher performance supported by job satisfaction. The direct effect of performance allowance on teacher performance is $22.1 \%$, while the indirect effect of performance allowance on teacher 
performance mediated by job satisfaction is $2.0 \%$. This shows that the direct effect is greater than the indirect effect of performance allowance on teacher performance without going through job satisfaction. This means that job satisfaction can mediate the effect of performance allowance on teacher performance even though it is small. This result is seen from the significance value of 0.037 which is smaller than $\alpha(0.05)$. Performance allowance will affect the performance of the teacher when the teacher feels satisfied or dissatisfied with the performance allowance provided. Teachers' performance will be maximal and continue to increase if the teacher is satisfied with the performance allowance provided by the school, and conversely, the teacher's performance will decrease if the teacher is disappointed with the performance allowance of the company. Performance allowance that is given fairly will make the teacher more satisfied and will ultimately affect the teacher's performance. Thus, teacher performance will increase or decrease according to the level of teacher job satisfaction on performance allowance provided by the school (Luthan, 2009).

Job satisfaction mediates the effect of work discipline on teacher performance. This means that indicators of work discipline can improve teacher performance supported by job satisfaction. The direct effect of work discipline on teacher performance is $15.3 \%$, while the indirect effect of work discipline on teacher performance mediated by job satisfaction is $1.9 \%$. This shows that the direct effect is greater than the indirect effect of work discipline on teacher performance without going through job satisfaction. This means that job satisfaction is able to mediate the effect of work discipline on teacher performance even though it is small. This result, seen from the significance value of 0.034 , is smaller than $\alpha(0.05)$. Additionally, job satisfaction needs to be supported by a good work environment in the form of a work environment that can support efficiency, security, safety, cleanliness, and comfort in work, and also the existence of adequate facilities make employees feel safe, calm and happy in carrying out their assigned duties and responsibilities, so that satisfaction arises in the teacher. Higher work discipline will be able to help improve performance (Luthan, 2009).

Job satisfaction mediates the effect of leadership on teacher performance. This means that indicators of leadership are able to improve teacher performance supported by job satisfaction. The direct effect of leadership on teacher performance is $11.9 \%$, while the indirect effect of leadership on teacher performance mediated by job satisfaction is $2.3 \%$. This indicates that the direct effect is greater than the indirect effect of leadership on teacher performance.

Syslová (2019) stated that teacher performance is influenced by education level. However, current research shows that work benefits, work culture, and leadership have the most influence on teacher performance. Baier et al. (2019) found that the quality of learning is largely determined by the quality of the teacher, whereas in the current study the quality of the teacher can be improved by consistently improving work culture and periodic work benefits. Chetty et al. (2019) stated that teacher teaching styles affect student learning achievement significantly, current research states that teacher teaching styles can be improved with good leadership and work culture. Bahri et al., (2018) stated that teacher performance is not greatly influenced by work discipline. However, 
current research shows that work discipline is supported by a good work culture. Huyghebaert et al., (2018) found Excessive workload and commitment is not good for improving teacher performance, so that in current research a reasonable work culture is needed. This research has contributed in providing a comprehensive analysis that teacher job satisfaction is not only related to salary and work benefits, but also related to the work culture of organizations in schools and the quality of school leaders.

\section{CONCLUSION}

The results of the study indicate that the variables of performance allowance, work discipline, work culture and leadership directly and positively have a significant effect on job satisfaction and teacher performance. The indirect job satisfaction can mediate the effect of variables of performance allowance, work discipline, work culture and leadership on teacher performance in the Jember Regency.

The limitation in this study is that this research was carried out on teachers at the elementary school level, so that it could not be generalized on a secondary school level. The samples of this study were only taken from teachers who were civil servants and did not involve teachers who were non-permanent teachers who may give different conclusions.

Future research can be carried out by comparing research variables to respondents from other districts or by emphasizing the unit of analysis on principals. In addition, research can also be carried out on other variables and not only focus on teacher performance.

\section{REFERENCES}

Afshar, H. S., \& Doosti, M. (2016). investigating the impact of job satisfaction/dissatisfaction on Iranian English teachers' job performance. Iranian Journal of Language Teaching Research, 4(1), 97-115.

Alonderiene, R., \& Majauskaite, M. (2016), Leadership style and job satisfaction in higher education institutions. International Journal of Educational Management, 30(1), 140-164. doi: 10.1108/IJEM-08-2014-0106.

Amalia B., \& Pilarta, E. (2015). Job satisfaction and teachers performance in Abra state institute of sciences and technology. Global Journal of Management and Business Research, 15(4-A), 81-85.

Bahri, S., Basalamah, S., Kamse, J., \& Bijang, J. (2018). The effect of Islamic leadership, competence and compensation on work dicipline and teacher performance of madrasah Aliyah in Makassar city. International Journal of Scientific and Technology Research, 7(12), 137-143.

Baier, F., Decker, A-T., Voss, T., Kleickmann, T., Klusmann, U., \& Kunter, M. (2019). What makes a good teacher? the relative importance of mathematics teachers' cognitive ability, personality, knowledge, beliefs, and motivation for instructional quality. British Journal of Educational Psychology, 89(4), 767-786. doi: 10.1111/bjep.12256. 
Bass, B. M., \& Avolio. B. J., (2002). Impact of transformational leadership on follower development and performance: A field experiment. Acad. of Manag. J, 45(4), 735-744.

Birnbaun, D. (1998). Work related commitment and job performance: it's also the nature of the performance that counts. J. of Organizational Behavior, 19(1), 621-634.

Burns, J. M. (2003). Transforming leadership: A new pursuit of happiness. NY: Grove.

Byars-Rue. (2004). Human resource management. New York: McGraw-Hill.

Cedaryana, Luddin M. R., \& Supriyati Y. (2015). Influence of work discipline, career development and job satisfaction on employee performance directorate general research and development of ministry research, technology and higher education. International Journal of Scientific Research and Management, 6(2), 87-96.

Chetty, N. D. S., Handayani, L., Sahabudin, N. A., Ali, Z., Hamzah, N., Rahman, N. S. A., \& Kasim, S. (2019). Learning styles and teaching styles determine students' academic performances. International Journal of Evaluation and Research in Education, 8(4), 610-615. doi:10.11591/ijere.v8i3. 20345.

Colquitt, J., LePine, J., \& Watson, M. (2009). Organizational behavior. NY: McGrawHill.

Dessler, G. (2010). Human resources management. McGraw-Hill Companies.

Elqadri, Z. M., Wardoyo D. T. W., \& Priyono. (2015). The influence of motivation and discipline work against employee work productivity Tona'an Markets. Review of European Studies, 7(12), 173-181.

Fashiku, C. O. (2016). Leaders' communication pattern: A predictor of lecturers' job performance in Nigeria. Int. J. of Edu. Leadership and Management, 4(2), 103-126.

Hair, J. F., William, C. B., Barry, J. B., \& Rolph, E. A. (2010). Multivariate data analysis. New Jersey: Pearson.

Hewett, R., Shantz, A., Mundy, J., \& Alfes, K. (2018). Attribution theories in human resource management research: A review and research agenda. International Journal of Human Resource Management, 29(1), 87-126. doi:10.1080/09585192.2017.1380062.

Hutabarat, W. (2015). Investigation of teacher job-performance model: Organizational culture, work motivation and job-satisfaction. Asian Social Science, 11(18), 295-304. doi:10.5539/ass.v11n18p295

Huyghebaert, T., Gillet, N., Beltou, N., Tellier, F., \& Fouquereau, E. (2018). Effects of workload on teachers' functioning: A moderated mediation model including sleeping problems and overcommitment. Stress and Health, 34(5), 601-611. doi: 10.1002/smi.2820.

Ibojo, B. O., \& Asabi, O. M. (2014). Compensation management and employees performance in the manufacturing sector: A case study of a reputable organization in the food and beverage industry. Int. J. of Managerial Studies and Res., 2(9), 108-117. 
Ivancevich, J., \& M. Matteson. (2005). Organizational behavior management. McGraw Hill.

Jamil, B., \& Raja, N. S. (2011). Impact of compensation, performance evaluation and promotion practice on government employees performance versus private employees performance. Interdisciplinary J. of Contemporary Research in Business, 3(8), 907-913.

Laurian-Fitzgerald, S., \& Fitzgerald, C. (2017), Teacher citizenship behavior. Education and Applied Didactics, 1(1), 26-35.

Liu, S., Hallinger, P., \& Feng, D. (2016). Supporting the professional learning of teachers in China: does principal leadership make a difference? Teach. Teach. Educ. 59, 79-91. doi: 10.1016/j.tate.2016.05.023.

Luthans, F. (2009). Organizational behavior. New York: McGraw-Hill Inc.

Mertler, C. A. (2016). Should I stay or should I go? Understanding teacher motivation, job satisfaction, and perceptions of retention among Arizona teachers. International Research in Higher Education, 1(2), 34-45. doi: 10.5430/irhe.v1n2p34.

Miao, C., Humphrey, R. H., \& Qian, S. (2018). A cross-cultural meta-analysis of how leader emotional intelligence influences subordinate task performance and organizational citizenship behavior. Journal World Bus, 53, 463-474. doi: 10.1016/j.jwb.2018.01.003.

Micheli, P., \& Neely, A. (2010). Performance measurement in the public sector in England: Searching the golden thread. Public Administration Review, 70(4), 591-600.

Mphil, A. M., Ramazan, M., Zubair, H. M. K., Ali, G., \& Arslan, M. (2014). Impact of compensation on employee performance (Empirical evidence from banking sector of Pakistan). International Journal of Business and Social Science, 5(2), 302-309.

Munawaroh, A., Riantoputra C. D. S., \& Marpaung S. B. (2013). Factors influencing individual performance in an Indonesian government office. The South East Asian Journal of Management, 5(2), 51-60.

Nugroho, F., \& Hastuti, H. (2019). Constraints of geography teacher of SMA N 1 Ngaglik in developing the 2013 curriculum learning devices in Sleman regency. Geosfera Indonesia, 4(1), 44-55. doi: 10.19184/geosi.v4i1.9294.

Odebode, A. A. (2018). Influence of psychosocial factors on job performance of female teachers in Kwara state, Nigeria. International Journal of Instruction, 11(3), 233-248. doi: 10.12973/iji.2018.11317a.

Opshal, R. L., \& Dunnette M. A. (1996). The role of financial compensation in industrial motivation. Psychological Bulletin, 66(2), 94-118.

Osborn, D., \& Gabler T. (1992). Reinventing government: How the entrepreneurial spirit is transforming the public sector. New York: Addison-Wesley. 
Quddus, S. M. A., \& Ahmed, N. U. (2017). The role of leadership in promoting quality management: A study on the Chittagong city corporation, Bangladesh. Intellectual Discourse, 25, 677-685.

Riaz, A., \& Haider, M. H. (2010), Role of transformational and transactional leadership on job satisfaction and career satisfaction. Business and Economic Horizons, 1, 29-38. doi: 10.15208/beh.2010.05.

Rizal, M., Idrus M. S., Djumahir, \& Mintarti, R. (2014). Effect of compensation on spirit at work, emotional intelligence and performance. International Journal of Business and Management Invention, 3(2), 64-79.

Robbins, S. P. (2006). Organization behavior. New Jersey: Person Education Inc.

Saeed, R., Mussawar S., Lodhi, R. N., Iqbal A, Nayab H. H., \& Yaseen, S. (2013). Factors affecting the performance of employees at work place in the banking sector of Pakistan. Interdisciplinary J. of Contemporary Research in Business, 17(9), 1200-1208.

Smith, H.W. (1975). Job satisfaction. New Jersey: Prentice-Hall.

Song, J. H., Chai, D. S., Kim, J., \& Bae, S. H. (2018). Job performance in the learning organization: The mediating impacts of self-efficacy and work engagement. Perf. Improvement Quarterly, 30(4), 249-271. doi:10.1002/piq.21251.

Strauss, G., \& Corbin S. L. (1990). Personnel management: Man on organization. New Jersey: Person Education Inc.

Stroganova, O., Bozhik, S., Voronova, L., \& Antoshkova, N. (2019). Investigation into the professional culture of a foreign language teacher in a multicultural classroom from faculty and international students' perspectives. Education Sciences, 9(2) doi: 10.3390/educsci9020137.

Susilowati, C. (2013). The influence of organizational culture and individual competence on teacher performance: In the learning organization perspective (a study on elementary school teachers in Ternate city). International Journal of Business and Behavioral Sciences, 3(8).

Syslová, Z. (2019). The relation between reflection and the quality of a preschool teacher's education performance. International Journal of Child Care and Education Policy, 13(1) doi: 10.1186/s40723-019-0060-y.

Talabi, A. S. (2016). Job satisfaction and work performance of public secondary school teachers in Akoko North West local government area of Ondo state. Journal of Arts and Humanities, 5(8), 39-49.

Toha, M., \& Katoningsih, S. (2018). The effect of leadership, organizational culture, and competency on teachers' performance in ibu kartini vocational high school Semarang. AIP Conference Proceedings 1941, O20044(2018), https://doi.org/10.1063/1.5028102.

Yamoah, E. E. (2013). Relationship between compensation and employee productivity. Journal of Business Economics and Management Studies, 2(1), 73-79. 